\title{
縦渦の定常揚力により駆動する円柱翼風車の抗力特性
}

\section{Drag force of circular cylinder blade wind turbines driven by steady lift force of longitudinal} \\ vortex \\ Kasumi SAKAMOTO*1 ${ }^{*}$, Withun HEMSUWAN ${ }^{* 2}$ and Tsutomu TAKAHASHI ${ }^{* 3}$ \\ ${ }^{* 1}$ Department of Science of Technology Innovation, Nagaoka University of Technology \\ 1603-1 Kamitomioka-machi, Nagaoka-shi, Niigata 940-2188, Japan \\ ${ }^{* 2}$ School of Mechanical Engineering, Suranaree University of Technology \\ 111 University Avenue, Muang District, Nakhon Ratchasima 30000, Thailand \\ ${ }^{* 3}$ Department of Mechanical Engineering, Nagaoka University of Technology \\ 1603-1 Kamitomioka-machi, Nagaoka-shi, Niigata 940-2188, Japan
}

坂本 夏澄"1，Withun HEMSUWAN*2，高橋 勉"3

Received: 19 October 2020; Revised: 27 December 2020; Accepted: 18 January 2021

\begin{abstract}
The effects of the configurations and structural parameters of the cylinder blade wind turbine driven by the steady lift force of the longitudinal vortex on its rotation and drag force characteristics were investigated. When the longitudinal vortex was formed stably behind the moving direction of the cylinder blade, a negative pressure region was generated between the cylinder blade and the wake ring-plate. This negative pressure region applies the drag force on the cylinder blade in the mainstream direction simultaneously with the driving force in the rotation direction. The drag force was generated by the irregular formation of the necklace vortex when the cylinder blade was fixed, but the drag force increased even more when the necklace vortex became stable with the rotation. A complicated behavior of drag coefficients with increasing flow velocity was observed for the singlecylinder blade due to the influence of the inner region of a ring-plate and the tip-ends of the cylinder blade. In the case of the stepped cylinder blades, in which the unnecessary region where the influence of the necklace vortex does not occur was removed, the drag coefficient remained almost constant regardless of the flow velocity, and the formation of the necklace vortex was stabilized. In the multiple stepped cylinder blade wind turbine, the rotational speed increased by the effect of adjacent blades. The drag force acting on the entire wind turbine increased with the increasing of the blade number, but the drag force per blade was almost constant.
\end{abstract}

Keywords : Renewable energy, New wind turbine, Circular cylinder blades, Longitudinal vortex, Steady lift force, Drag force, Wind tunnel experiment

\section{1. 緒言}

流れに直交する円柱の下流に円柱または円柱の直径と同程度の幅を持つ平板を置き十字交差させると，交差部 から流れ方向に回転軸を持つ縦渦が発生する。縦渦は図 1(a)に示すトレーリング渦（trailing vortex, TV）と図 1(b) に示すネックレス渦（necklace vortex, NV）の 2 種類の形態が存在し，その形態は交差する構造物間のすき間 $s$ を 上流の円柱直径 $d$ で無次元化した $s / d$ によって決定される(Takahashi et al., 1999). これらの縦渦はカルマン渦と同 様に上流円柱の下流において円柱の上面側，下面側において周期的に形成・消失を繰り返す.この周期は構造物 の形状因子および流速に依存して変化する. 縦渦の周期的形成に伴い上流円柱には変動揚力が作用するため，上 流円柱を弾性支持し下流に円柱を配置した円柱/円柱系十字交差配置では，縦渦による渦励振現象，すなわち縦渦

No.20-00375 [DOI:10.1299/transjsme.20-00375], J-STAGE Advance Publication date : 27 January, 2021

*1 正員, 長岡技術科学大学大学院 工学研究科 技術科学イノベーション専攻（广940-2188 新潟県長岡市上富岡町 1603-1）

${ }^{* 2}$ School of Mechanical Engineering, Suranaree University of Technology (Address: 111 University Avenue, Muang District, Nakhon Ratchasima 30000, Thailand)

*3 正員, 長岡技術科学大学大学院 工学研究科 機械創造工学専攻

E-mail of corresponding author: ttaka@nagaokaut.ac.jp 
励振現象が発生する(Kato et al., 2012, Koide et al., 2006, 2017). 縦渦励振はカルマン渦励振よりも広い同期領域を持 ち, さらに 3 倍程度の振動振幅を生み出す強い励振力を有する(Kumagai et al., 2001, Nguyen et al., 2010, 2012, Takahashi et al., 1999, Shirakashi et al., 1989, 1994)．また，上流円柱直径と同程度の幅 $W$ を持つ平板を十字交差配置 させた円柱/平板系において，無次元すき間 $s / d$ および無次元平板幅 $W / d$ は，縦渦が有する渦流出周波数，縦渦に よる周期的な揚力の発生, 上流円柱の振動振幅などを支配する重要な形状因子であることが報告されている(Kato et al., 2012).

上述のように十字交差配置した構造物間に形成される縦渦は強い変動揚力を有することから, 縦渦はカルマン渦より も強い流体力を発生させ，上流円柱の下流側の上面あるいは下面のいずれかに縦渦を定在化することで定常揚力を誘 起できると予想した. 縦渦の定在化を実現する方法として, 円柱/平板系十字交差配置において上流円柱を一定の速度 で下流平板に沿って平行移動する方法を発案した．円柱まわりの流れ場は主流と円柱の移動速度の合成により相 対迎角が生じ，後流域に存在する平板により円柱の移動方向とその反対側では非対称な流れ場が形成される. 円 柱の寸き間と移動速度が所定の条件を満たすとき，縦渦は図 1(c)に示すように円柱と平板の交差部において円柱 の移動方向と反対側の後流に定在的に形成される. このとき, 円柱の進行方向前方の流れは平板とのすき間を通 り縦渦に吸い込まれ, 円柱の進行方向側に強い負圧領域が発生し, 定常揚力となる. この現象を利用して, 円柱 の運動を流れに垂直な平行移動を回転運動に変更し，下流に設置する平板をリング状にすることで，図 2 のよう な縦渦により駆動し回転するという新たなコンセプトによる風車を提案した(Takahashi et al., 2016, 高橋他, 2016). 数值解析により, 円柱/平板系十字交差配置において上流円柱を一定の速度で下流平板に沿って平行移動させると き, 縦渦の一つであるネックレス渦が円柱と平板の交差部において円柱に相対的に静止して形成され, 円柱の前 方に強い吸い込み領域を誘導し円柱に定常揚力を発生させることを確認した(Hemsuwan et al., 2018). 坂本らは風 洞を使用した実験により，無次元すき間 $s / d$ が 0.35 , 寸なわち，ネックレス渦が流出する条件で円柱翼風車は定 常回転することを確認した．また，風洞に煙を流し込むことによる可視化を行い，Hemsuwan ら(2018)によって解 析されたとおり，円柱翼が定常回転するとき，円柱翼とリング状平板の交差部にはネックレス渦が円柱翼の回転 に追従しながら定在的に形成されることを示した. さらに, 円柱翼に作用寸る流体力と円柱翼の回転速度から求 められる相対迎角の関係を求め, 円柱翼風車の動力特性との関係を明らかにした(坂本他, 2021). Hemsuwan らの 円柱/平板系十字交差配置に関する報告において図 1(c)に示す上流円柱の移動方向に作用寸る揚力と, 主流方向に作 用寸る抗力の各係数の評価が行われ, 円柱の長手方向にわたる局所的な揚力係数, 抗力係数の分布が明らかにされた (Hemsuwan et al., 2018). 局所抗力係数は主流速度に対する円柱の移動速度の比（すなわち速度比） $V R=0.05 \sim 0.2$ の 範囲において円柱と平板の交差部中心で極小值を示し, 交差部中心から遠ざかるにつれて増加し, 平板の縁付近で極 大值を取った後, 円柱末端に向けて急激に低下した. また, 円柱全体にわたる抗力係数 $C_{d}$ は, $V R=0.05 \sim 0.2$ において $C_{d}=1.2 \sim 1.4$ 程度となった. 同じレイノルズ数域での円柱の一般的な抗力係数は $C_{d} \sim 1.2$ (Schlichting and Gersten, 2017)で あるため, 縦渦の形成によりわずかに大きくなることが示された. 一方で, $V R$ の増加に対し揚力係数 $C_{l}$ は連続的に減少 した.

上記のように, Hemsuwan らの数值解析により上流円柱に作用寸る抗力は主流により受ける通常の抗力に加えて, 円 柱と下流平板の寸き間に形成されるネックレス渦が強く影響することが示された. ネックレス渦の吸い込みを動力とする円 柱翼風車においても, 抗力は通常の風車以上に動力特性に大きく関係するものと予想される. そこで本研究では, 風洞 実験により円柱翼風車の翼に作用する回転数と抗力を測定し, 円柱翼風車の主要な形状因子, 寸なわち円柱翼とリング 状平板の寸き間や翼形状, 翼数などがこれらに及ぼす影響を明らかにすることを目的とする. 


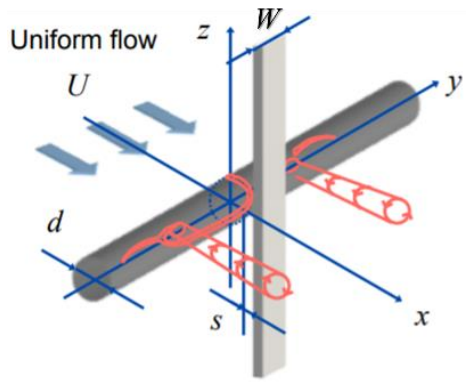

(a) Trailing vortex $(0<s / d \leq 0.25)$

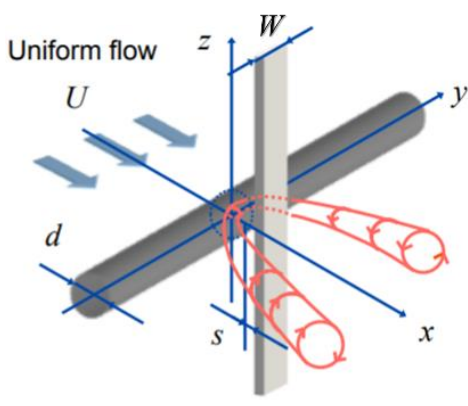

(b) Necklace vortex $(0.25 \leq s / d \leq 0.5)$

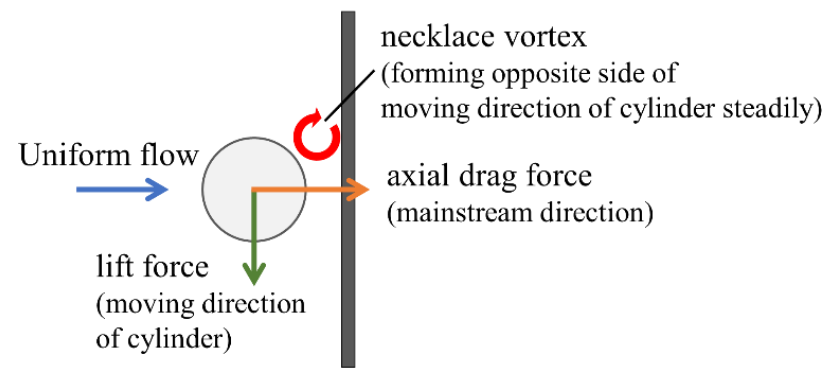

(c) Necklace vortex and fluid forces acting on the upstream circular cylinder at cross-section of cruciform system

Fig. 1 Longitudinal vortices of cruciform system of upstream cylinder and downstream strip-plate (Takahashi et al., 1999).

\section{2. 実験装置および実験手順}

\section{$2 \cdot 1$ 円柱翼風車の構造と円柱翼の形状}

1 本の長い円柱を動翼として用いた円柱翼風車の写真および概略図を図 2 に示寸．この風車を単独円柱翼風車 とよぶことにする. 直径 $d=20 \mathrm{~mm}$ ，長さ $L=220 \mathrm{~mm}$ の塩ビパイプで作製された円柱翼は，長さ $L$ の中心に回転軸 を固定し動翼とした．下流のリング状平板の寸法は，リング幅の中心における直径 $D=155 \mathrm{~mm}$, 厚さ $3 \mathrm{~mm}$ を一定 とし，幅は $W=15,20 ， 30 \mathrm{~mm}$ の 3 種類を用意した. 円柱翼との寸き間比は $s / d=0 \sim 0.5$ の範囲で任意の值に設定可 能である.

単独円柱翼風車の円柱翼において, 縦渦による動力発生に不要と考えられる領域は回転に対する空気抵抗とな り動力特性を低下させる.この領域の直径を小さくすることで回転方向および主流方向の流動抵抗を下げると同 時に多翼化による回転中心部近傍のソリディティを下げることができる.リング状平板幅より外側の部分は短く, 回転軸に近い内側の部分は直径を小さくした円柱翼を段付き円柱翼とよぶことにする. 翼数 $N=8$ の段付き円柱翼 風車の写真および $N=2$ の概略図を図 3 に示す. リング状平板の寸法は $D=155 \mathrm{~mm}, W=20 \mathrm{~mm}$ ，厚さ $3 \mathrm{~mm}$ 一定と し, 円柱翼との寸き間比は $s / d=0 \sim 0.5$ の範囲で任意の值に変更可能である. 円柱翼はテフロン製で, 回転軸に固定 された直径 $\varphi 30 \mathrm{~mm} ，$ 幅 $20 \mathrm{~mm}$ のハブに円周上に最大 12 本まで等間隔で取り付けられる. 円柱翼のネックレス渦 の揚力が作用する有効部分の直径 $d=20 \mathrm{~mm}$, 回転軸に近い支持部の直径 $d^{\prime}=6 \mathrm{~mm}$, 有効部分のリング状平板の内 外縁からの突き出し長さは $l_{P}=10 \mathrm{~mm}$, 寸なわち, 有効部分の長さは $l=40 \mathrm{~mm}$ とした. 円柱翼の全長は $L=195 \mathrm{~mm}$ で ある。 


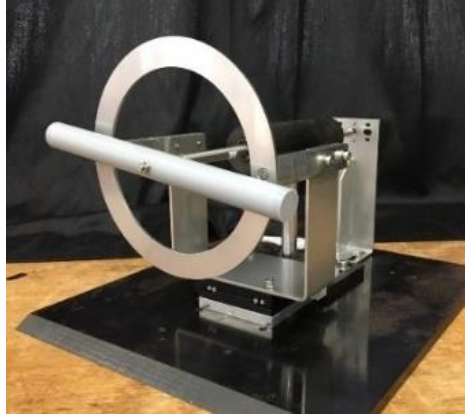

(a) Photograph of apparatus
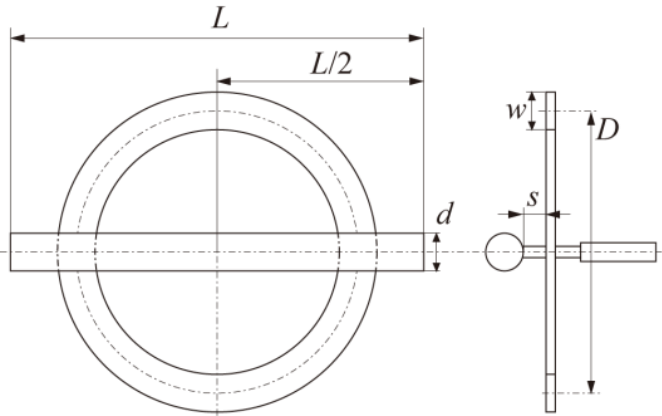

(b) Schematic diagram and parameters

Fig. 2 Photographs and schematic diagrams of single-cylinder blade wind turbine.

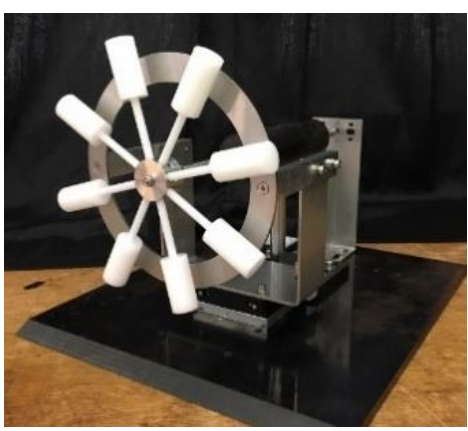

(a) Photograph of apparatus $(N=8)$
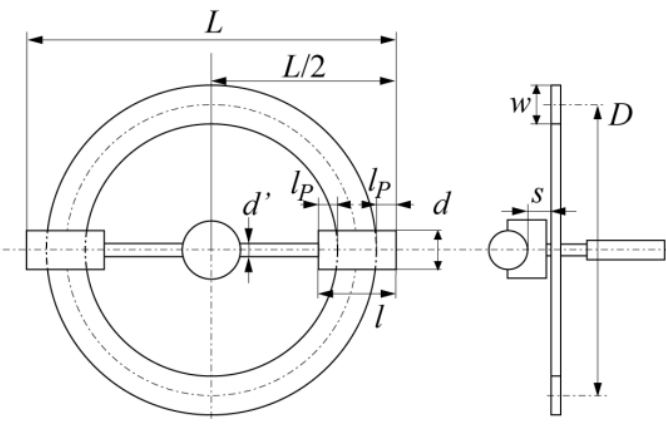

(b) Schematic diagram and parameters $(N=2)$

Fig. 3 Photographs and schematic diagrams of stepped cylinder blade wind turbine.

\section{$2 \cdot 2$ 縦渦による抗力の評価}

円柱翼に作用する流体力のうち主流方向の成分である抗力を測定し，全抗力に含まれるネックレス渦の形成に よる増加分を評価する．ネックレス渦が安定的に形成されるとき円柱翼には揚力が作用する. 同時に, 円柱翼を 下流のリング状平板側に吸い寄せる力も作用する．後者は円柱翼に作用する抗力と同じ方向の力であり，円柱翼 に作用する抗力として測定される力に含まれる. 円柱翼に作用する揚力の増加は抗力の増加も引き起こすと予測 される. そこで, 測定される円柱翼の全抗力からネックレス渦の形成に伴う抗力の増加分を定量化し, ネックレ ス渦の形成状態を表す指標として評価する。これにより，縦渦により駆動される円柱翼において必要最低限の長 さの評価や，ネックレス渦の安定形成に係わる条件を明らかにするそそのための測定装置と実験方法について以 下に説明する.

円柱翼に作用する抗力を測定する装置の全体像および仕組みの概略図を図 4 に示す. 円柱翼の回転軸は図 4(a)の 写真の中央部にある黒い円筒状の軸受けにより保持される. 軸受けにはスラスト・ラジアル複合ベアリング(日本ベアリン グ株式会社)を使用した.これにより回転軸の回転抵抗が低減されるだけではなく, 軸方向に対しても滑らかに移動が可 能となっている. 回転軸の下流側の先端はニードル状になっており, 風圧がかかっても回転方向のまさつ抵抗が低減さ れる構造とした. 回転軸の先端のニードルは引張・圧縮用ロードセル（LTS-500GA，株式会社共和電業）の測定軸に 取り付けられた金属板に接し, 円柱翼に作用寸る軸方向の力はロードセルとアンプを通じて電圧として出力され, $\mathrm{AD}$ 変換器により $\mathrm{PC}$ に記録される. 事前に求めた校正式により電圧を力に変換する. 各条件において抗力は 10 秒間に測定された值の平均值として求めた。ロードセルやアンプのドリフトなどの誤差を低減するために，実験 毎にロードセルの校正を行い，校正式の確認を行った.

円柱翼に作用する全抗力中のネックレス渦による増加分を明らかにするために以下の 3 つの条件で抗力測定を 行う.

(1) 円柱翼，リング状平板が取り付けられ，円柱翼が自由に回転する（回転円柱，Rotating cylinder）

(2) 円柱翼, リング状平板が取り付けられ, 円柱翼が固定され回転しない（固定円柱, Fixed cylinder)

(3) リング状平板が取り外され，円柱翼のみが取り付けられている（円柱のみ，Cylinder only） 
これら 3 つの実験条件に対する実験装置の写真を図 5 に示す. (2)の実験条件では図 5(b)に示すように主流方向に 平行になるように取り付けられた断面 $5 \mathrm{~mm}$ 程度の棒で挟み込むことで円柱翼を固定する. 固定用の棒は回転軸 に近い位置にあるためネックレス渦の形成には影響を与えない. (2)の円柱翼が固定されている条件ではネックレ ス渦は円柱翼とリング状平板の寸き間において周期的，あるいは不規則に形成と消失を繰り返し，定常的な揚力 は発生しない. (3)のリング状平板が取り外された条件ではネックレス渦は形成されない. これらの結果を比較す ることでネックレス渦の定常的な形成による抗力の増加分を検討する.

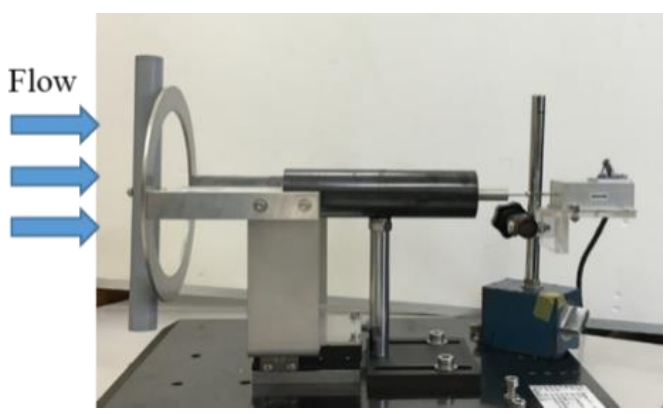

(a) Setting of load cell in experimental apparatus

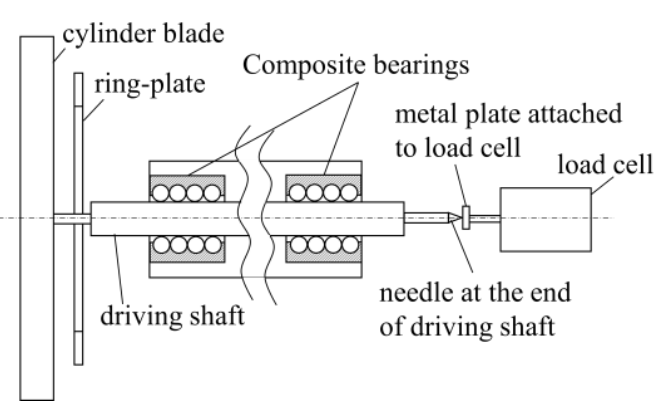

(b) Schematic diagram of mechanism of experimental apparatus Fig. 4 Setting method of load cell into single-cylinder blade wind turbine.

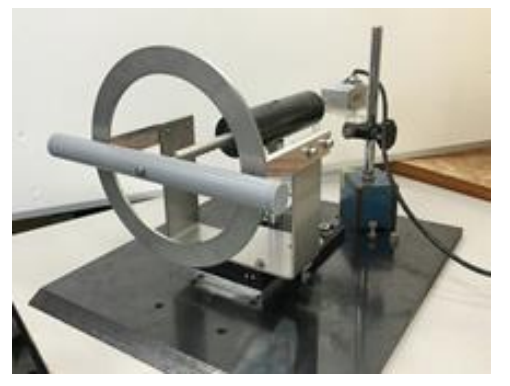

(a) Rotating cylinder

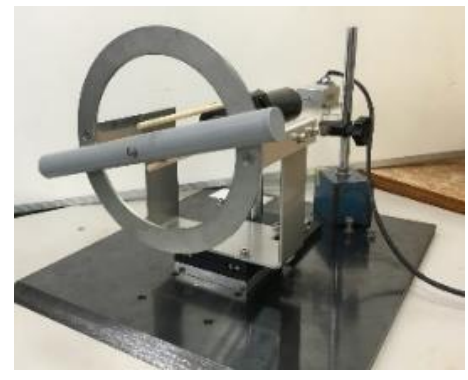

(b) Fixed cylinder

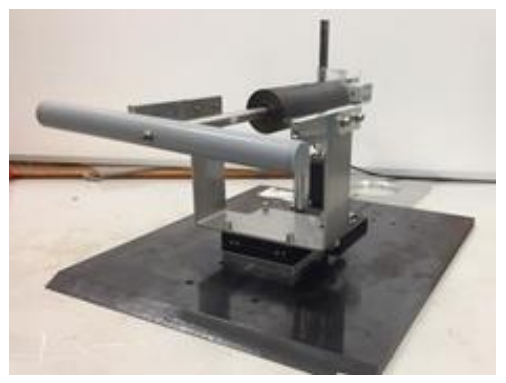

(c) Cylinder only

Fig. 5 Setting conditions for measurement of drag force.

\section{$2 \cdot 3$ 風洞装置}

風車装置は図 6 に示寸ように風洞の吹出し口に取り付けられたテストセクションに設置される. テストセクシ ヨンの断面は一辺 $320 \mathrm{~mm}$ の正方形で長さは $1200 \mathrm{~mm}$ であり，速度範囲は $U=2 \sim 40 \mathrm{~m} / \mathrm{s}$ ，乱流強度は $0.3 \sim 0.6 \%$ の範 囲である(Kato et al., 2012). 風車は, 円柱翼の受風面がテストセクションの入口から $840 \mathrm{~mm}$ 下流, 回転軸はテス トセクション断面の中心に位置するように設置される. テストセクション内の流速はリング型流速計(小出他, 2001)により測定され，その熱線プローブの先端がテストセクション入口から $200 \mathrm{~mm}$ 下流に位置する.

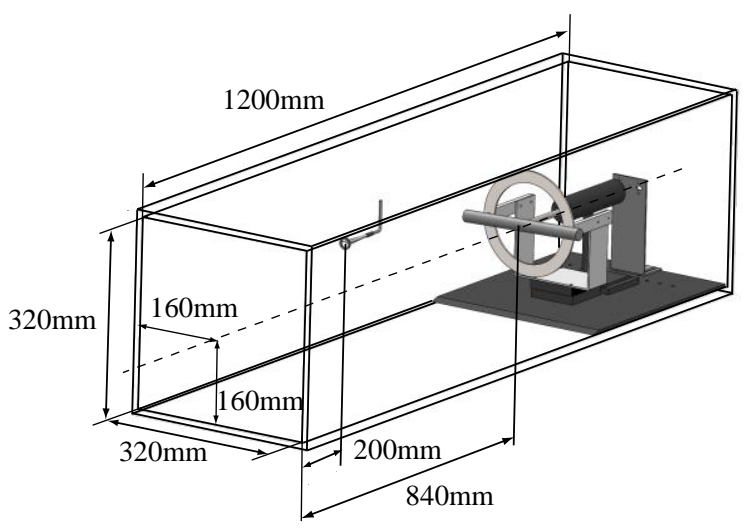

Fig. 6 Schematic diagram of test section and wind turbine setting. 


\section{$2 \cdot 4$ 実験条件}

単独円柱翼風車を用いた実験でははじめに幅 $W=20 \mathrm{~mm}$ のリング状平板に関して，抗力に対するすき間比の影 響を調べる. 一定流速下 $U=12 \mathrm{~m} / \mathrm{s}$ ですき間比 $s / d$ を 0.2 から 0.5 まで段階的に増加させた際の回転円柱および固 定円柱の抗力 $F_{d}$, 回転円柱の回転数 $n$ を測定した. $n$ は, 回転軸の回転数を非接触光学式タコメータ（AT-6, 株 式会社 エムケー・サイエンティフィック）により求めた．加えて，円柱のみ $(s / d=\infty)$ 場合の $U=12 \mathrm{~m} / \mathrm{s}$ 一定下の $F_{d}$ を測定した. 次に幅 $W=15,20,30 \mathrm{~mm}(W / d=0.75,1.0,1.5)$ のリング状平板に対して, すき間比を $s / d=0.35$ に 固定し, 流速を $U=2 \sim 12 \mathrm{~m} / \mathrm{s}$ で段階的に増加させた場合の回転円柱の $F_{d}$ および $n$ を測定した. 段付き円柱翼風車 を用いた実験では $W=20 \mathrm{~mm}, s / d=0.35$ 一定とし, 翼数 $N=2,4 ， 6 ， 8 ， 10 ， 12$ で流速を $U=2 \sim 12 \mathrm{~m} / \mathrm{s}$ で段階的に増 加させた際の回転円柱の $F_{d}$ および $n$ を測定した. 表 1 に, 以上で述べた各実験に用いられた円柱翼風車の形状条 件をまとめて示す.

Table 1 Parameters of experimental conditions.

\begin{tabular}{|c|c|c|c|}
\hline & \multicolumn{2}{|c|}{ Single-cylinder blade wind turbine } & Stepped cylinder blade wind turbine \\
\hline & $s / d-F_{d}, n$ & $U-F_{d}, n$ & $U-F_{d}, n$ \\
\hline Setting condition & $\begin{array}{l}\text { Rotating cylinder } \\
\text { Fixed cylinder }\end{array}$ & \multicolumn{2}{|r|}{ Rotating cylinder } \\
\hline Flow velocity $U[\mathrm{~m} / \mathrm{s}]$ & 12 & \multicolumn{2}{|r|}{$2 \sim 12$} \\
\hline Gap ratio $s / d[-]$ & $0.2 \sim 0.5, \infty$ & \multicolumn{2}{|r|}{0.35} \\
\hline Ring-plate width ratio $W / d[-]$ & 1 & $0.75,1,1.5$ & 1 \\
\hline Blade diameter $d[\mathrm{~mm}]$ & \multicolumn{2}{|c|}{20} & $20\left(d^{\prime}=6\right)$ \\
\hline Blade total length $L(L / 2)[\mathrm{mm}]$ & \multicolumn{2}{|c|}{$220(110)$} & $195(97.5)$ \\
\hline Ring-plate diameter $D[\mathrm{~mm}]$ & \multicolumn{3}{|c|}{155} \\
\hline Blade number $N$ & \multicolumn{2}{|c|}{ (2) } & $2 \sim 12$ \\
\hline Blade effective length $l[\mathrm{~mm}]$ & & & 40 \\
\hline Blade protruding length $l_{p}[\mathrm{~mm}]$ & & & 10 \\
\hline
\end{tabular}

\section{3. 実験結果および考察}

\section{$3 \cdot 1$ 綐渦の形成状態が抗力・回転特性に及ぼす影響}

図 7 にリング状平板幅を円柱翼直径で正規化したリング状平板幅比 $W / d=1.0$ の単独円柱翼風車の円柱翼に作用 する抗力の測定結果を示す. 主流速度 $U$ を $12 \mathrm{~m} / \mathrm{s}$ とし， $2 \cdot 2$ 節で説明した $3 つ の$ 条件，すなわち，(1)主流により 円柱翼が回転する条件, (2)抗力に影響を与えずに円柱翼の回転方向の動きを固定した条件, および(3)リング状平 板を取り除いた条件，について抗力 $F_{d}$ を求めた。(1)および(2)の条件では円柱翼直径で正規化した無次元すき間 $s / d$ を 0.2 から 0.5 の範囲で変化させて $F_{d}$ に及ぼす影響を求めた. さらに(1)では軸受けのまさつ以外の負荷がな い状況での円柱翼の回転数 $n$ も求めた. 図 7(a)に示寸ように $s / d<0.325$ の範囲において円柱翼は一方向への連続的 な回転は示さず, 初速を与えて回転させても回転は維持されず静止あるいは摇動状態となった. $0.2 \leq s / d \leq 0.25$ は図 1(b)に示したトレーリング渦が形成される条件であり, ネックレス渦による定常揚力は発生せず円柱翼は停止し たと考えられる. また， $s / d$ が 0.325 に近い值であるほど円柱翼は摇動した. これは $s / d$ の増加に伴いネックレス 渦の周期性が失われ始めネックレス渦が円柱翼の上側，または下側から定在的に形成されるが，円柱翼の角速度 が小さくネックレス渦が形成される位置が切り替わりやすいことを意味する. $s / d=0.325$ を越えると一定の方向に 突然回転を始めた. $s / d=0.325$ 付近において静止中の円柱翼にはネックレス渦が周期的に発生し変動揚力が作用す る. カットイン風速に近い低風速域では停止状態からネックレス渦による摇動が生じ，その角速度が所定の值を 超えたときにネックレス渦が安定的に形成され一方向に回転を続ける. 主流が十分に速い場合は静止状態から一 気に一方向に回転を始める. 回転の方向は初動方向に依存し，左右，どちらにも同確率で回転寸る．その後，s/d の増加とともに $n$ も低下した．全ての条件で測定された $F_{d}$ と $s / d$ の関係を図 7(b)に示す. 図 7(b)において(3)の円 
柱のみの条件における $F_{d}$ の結果は $s / d$ に関係しないため破線で示寸. $F_{d}$ は, (1), (2)の条件ともに $s / d=0.2$ から 0.3 付近の領域では $s / d$ によず一定で，破線で示した円柱のみの $F_{d}$ とほぼ同じ值を示した. $F_{d}$ は(1)の回転する円柱 翼では $s / d=0.325,(2)$ の回転方向には固定された円柱翼では $s / d=0.35$ で急激に増加したのち, $s / d$ の増加に伴い減 少した．このように，円柱翼が風車として回転する(1)の条件では静止円柱よりも $F_{d}$ が大きな值を示した. $s / d の$ 増加に伴い $F_{d}$ が一様に低下し $n$ も同様に一様に低下寸ることから, 風車を駆動するネックレス渦の作用は同時に $F_{d}$ も増加させることが示された. (2)の円柱翼が回転しない場合でも $s / d \geq 0.35$ の範囲においてはネックレス渦が形 成され $F_{d}$ が増加するが, 計測された值は(1)の回転する場合に比べてかなり小さく, ネックレス渦が不規則に形成 されている状態と推測される.

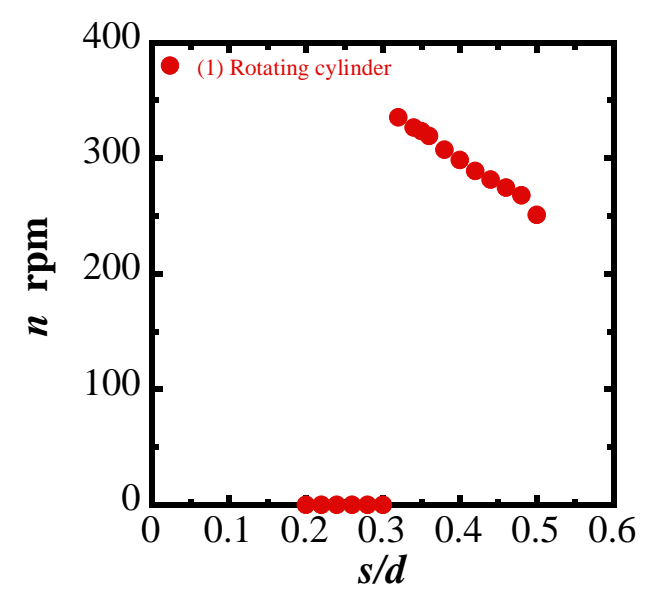

(a) Rotational speed vs. gap ratio at rotational cylinder

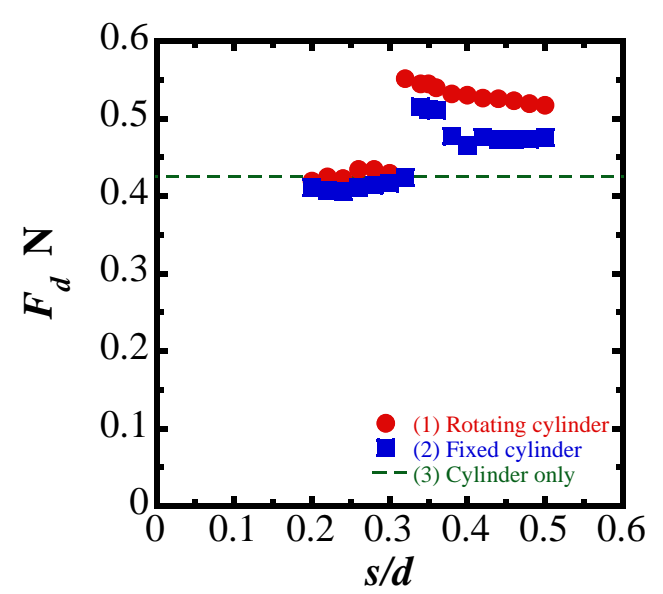

(b) Drag force vs. gap ratio

Fig. 7 The drag force and the rotational speed at three condition as a function of gap ratio ( $U=12 \mathrm{~m} / \mathrm{s}, W / d=1$, single-cylinder blade). The rotational speed is measured by the non-contact tachometer and the drag force is measured by the load cell. The cylinder blade starts to rotate and the drag force increases rapidly at $s / d=0.325$ in (1) Rotating cylinder, indicating that $s / d=0.325$ is the critical condition for the single-cylinder blade wind turbine to obtain the driving force from the necklace vortex.

\section{$3 \cdot 2$ 単独円柱翼風車の抗力・回転特性}

図 8(a)に単独円柱翼風車をすき間比 $s / d=0.35$ に設定し, 実験条件(1)の円柱翼が回転している状態に対する流速 $U$ と回転数 $n$ の関係を示寸. 円柱翼の直径 $d$ を $20 \mathrm{~mm}$ とし, リング状平板の幅は $W / d=0.75,1.0,1.5$ となる 3 種 類の条件について測定を行った. 図 8(a)より $W / d$ が大きいほど高回転となり，W/d=1.0 および 1.5 に関しては $U$ の増加に対して $n$ が直線的に増加したことが分かる. 著者らの先の報告(坂本他, 2021)で示したように, この $U$ と $n$ の関係は原点を通る比例の関係ではなく，ある速度 $U_{0}$ を基点とした直線になる. $W / d=1.0$ および 1.5 は実験結 果を外挿して $x$ 軸と交差した位置である $U_{0}$ がほぼ同じ值となり, $U$ に対する $n$ の増加率は $W / d=1.5$ のほうが 1.0 の場合より大きくなった，一方，W/d=0.75 では回転を始める流速および回転数は他の $W / d$ よりも大きくなった. また, $U$ の増加に対しても他の条件のような明確な直線関係ではなく, 高流速域で $n$ の増加が緩やかとなった. 図 8(b)に示寸同じ条件で測定した円柱翼に作用する抗力 $F_{d}$ と $U$ の関係を見ると, $W / d=1.5,1.0$ では基点となる流 速 $U_{0}$ を越えると $F_{d}$ は $U$ の増加に対して急激に増加した. $W / d=0.75$ においても $F_{d}$ は他の条件と同様に連続的に 増加した. 図 8(b)で示したように円柱翼が回転しない実験条件(2)においてもネックレス渦が形成され， $F_{d}$ はリン グ状平板がない条件(3)よりも高くなった．また，W/d=0.75のUが $2 \mathrm{~m} / \mathrm{s}$ から $4.5 \mathrm{~m} / \mathrm{s}$ にわたる円柱翼が回転しない 流速域においても $F_{d}$ が増加したことからネックレス渦が形成されていたことがわかる. 円柱翼が一方向への定常 回転を起こさないことでネックレス渦の形成は定在化せず時間平均的には揚力はゼロであるが， $F_{d}$ が増加してい ることからネックレス渦は円柱翼の斜め後方の上面または下面のいずれかには周期的あるいは不規則に発生して いたと考えられる.

図 8(b)で示した $U$ と $F_{d}$ の值をもとに式(1)と(2)により単独円柱翼の抗力係数 $C_{d}$ とレイノルズ数 $R e$ を求め, 図 9 にこれらの関係を示す. 


$$
\begin{aligned}
R e & =\frac{U d}{v} \\
C_{d} & =\frac{F_{d}}{0.5 \rho U^{2} d L}
\end{aligned}
$$

ここで，vは動粘度である．また，式(2)における $C_{d}$ の定義において代表長さとして円柱翼の全長 $L$ を使用してい る. 図 9 より, $W / d=0.75$ と 1.5 では $R e$ 増加により $C_{d}$ は単調に増加し, 高い $R e$ の領域になるにつれて増加率が緩 やかになった。 $W / d=1$ では, $R e<5000$ では $W / d=1.5$ の $C_{d}$ の值に近く, それより高い $\operatorname{Re}$ の領域では $W / d=0.75$ の值 に近くなった。リング状平板の幅 $W$ が大きいほどネックレス渦から流体力を受ける円柱翼の面積が増加するた め，ネックレス渦の強さが同じであれば円柱翼に作用する流体力は大きくなる. 回転数が W/dに依存して大きく なることから，W/d の増加に伴い揚力が大きくなることが理解できる．一方，円柱翼にはネックレス渦以外の渦 や流れ場が流体力として作用寸る. Hemusuwan らの数值解析は円柱と下流平板の近傍に形成されるネックレス渦 による流体力に加えて，翼端近傍に形成されるトレーリング渦が回転抵抗になることを示した(Hemsuwan et al., 2018). また，翼端にエンドプレートを付けることで回転抵抗を低減でき，さらに特定の形状のエンドプレートを 用いることで移動方向に作用する揚力を増加できることを示した。今回の実験で W/d を変化させたことは単純に ネックレス渦の影響範囲のスパン方向の長さを変えるだけではなく，翼端渦の効果や縦渦の形成領域以外の領域 における円柱翼の回転に対する流体抵抗の影響が現れたと考えられる. 特に $W / d=1.0$ で生じた $F_{d}$ の不連続的な変 化は $n$ には影響を与えないことからネックレス渦の状態が変わったのではなく，翼端渦あるいはネックレス渦の 影響を受けないリング状平板から離れた位置における回転に対する流体抵抗などによる主流方向の流体力の変化 を表していると予想される。

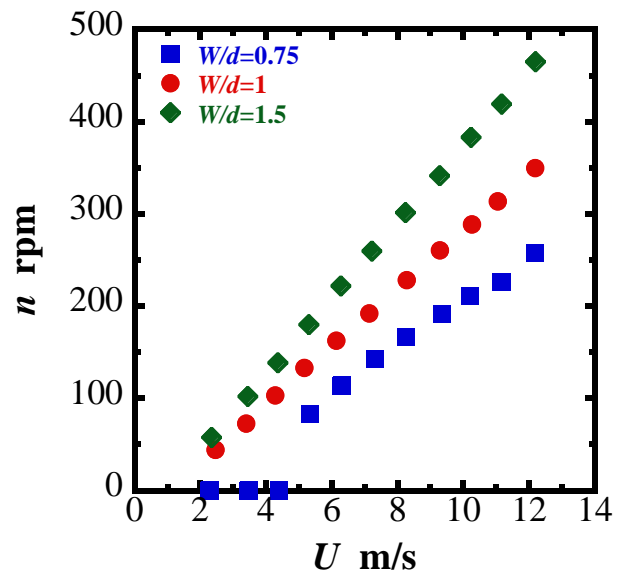

(a) Rotational speed vs. flow velocity

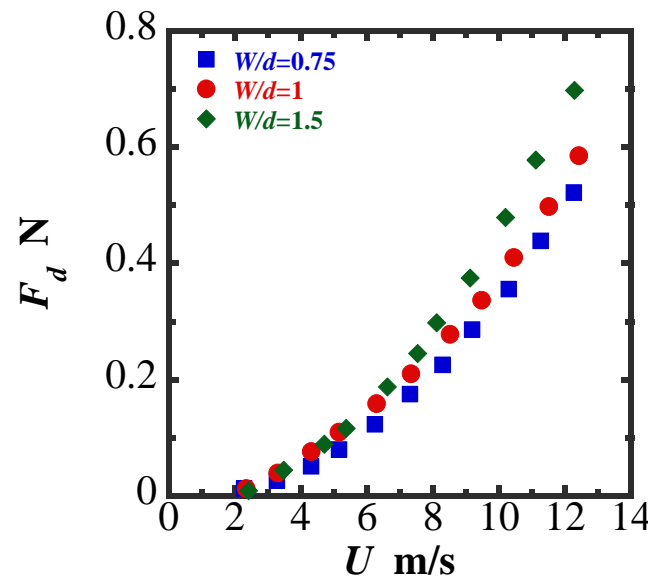

(b) Drag force vs. flow velocity

Fig. 8 The rotational speed and the drag force of rotating single-cylinder blade in each with ratio of ring-plate $W / d(s / d=0.35)$. As the flow velocity increases, the rotational speed increases linearly and the drag force increases rapidly. As the width ratio increases, the rotational speed and drag force increase at a constant flow velocity. 


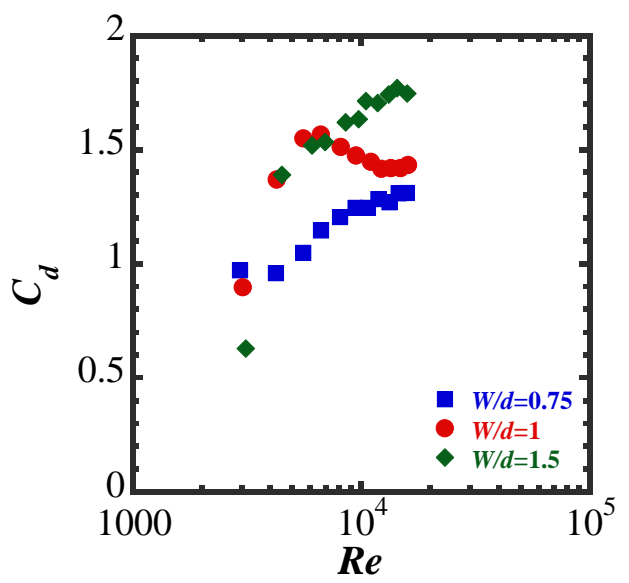

Fig. 9 The drag coefficient vs. Reynolds number calculated by Eqs. (1) and (2) in each with ratio of ring-plate $W / d(s / d=0.35)$. For $W / d=0.75$ and 1.5 , the drag coefficient increases monotonically with increasing $R e$, and the increase rate of the drag coefficient becomes smaller in the higher $R e$. For $W / d=1$, the drag coefficient approaches to the value of $W / d=1.5$ in $\operatorname{Re}<5000$, and approaches to the value of $W / d=0.75$ in the higher $R e$.

\section{$3 \cdot 3$ 単独円柱翼風車の抗力 - 回転特性}

上述のように単独円柱翼とリング状平板の交差部近傍に形成されるネックレス渦による流体力が作用する領域 以外のスパン方向の領域は，回転に対する流体抵抗および主流に対する円柱翼の投影面積（ソリディティ）を高 めて抗力 $F_{d}$ を増加させることから，風車としては負の特性を示す領域である. そこで，ネックレス渦による揚力 が効果的に作用する領域以外は円柱翼を保持するために必要な程度の太さに減じ，主流方向および回転方向への 流体抵抗を低減させることを試みる.このために作成したのが図 3 に示した段付き円柱翼風車である. Hemsuwan らの数值解析により円柱にネックレス渦による揚力が効果的に作用するのは，リング状平板と交差する領域およ びそれよりも外側と内側にそれぞれ 2 分の 1 円柱直径分だけ延長した範囲であることが分かっている(Hemsuwan et al., 2018). そこで本実験では段付き円柱翼の有効長さ $l$ を $40 \mathrm{~mm}$ とした $(W=20 \mathrm{~mm}, d=20 \mathrm{~mm})$. 段付きとして スパン方向の内側の直径を細くすることで多翼化も容易となる. 翼の枚数を $N$ として段付き円柱翼の抗力係数 $C_{d}$ を次式で定義する.

$$
C_{d}=\frac{F_{d}}{0.5 \rho U^{2} d l N}
$$

式(3)では段付き円柱翼全体に作用する抗力 $F_{d}$ に対して円柱翼 1 つの面積として $d l$ を使用している. $F_{d}$ には翼を 回転軸に固定するためのハブの投影面積，および段付き円柱翼の細い直径部分の面積に対する抗力成分も含まれ るが，式(3)の定義では煩雑さを避けるためにこれらを無視している.

図 10 に翼数 $N=2, W / d=1$ の段付き円柱翼風車の回転円柱（実験条件(1)）で，流速を段階的に増加させて測定し た $n$ と $U$ の関係, $F_{d}$ と $U$ の関係を示す. 寸き間比は $s / d=0.35$ である. 図 10 のそれぞれのグラフには比較のため に図 8 で示した $W / d=1$ の単独円柱翼風車の結果も併せて示す. 段付き円柱翼の $n$ は図 10(a)に示すように低流速 域では単独円柱翼の結果と完全に一致し, $U \geq 6 \mathrm{~m} / \mathrm{s}$ の範囲で単独円柱翼に対して数\%増加する程度であった. 一方, 図 10(b)に示すように $F_{d}$ は回転するほぼ全流速範囲で単独円柱翼の結果を大きく下回り，Uの増加に伴いその差 は大きくなった。この結果から, 円柱翼においてネックレス渦の流出に無関係と考えられる領域の削除は, ネッ クレス渦による揚力を保ちながら主流方向に作用する抗力を低下させる効果を持つことが示された. 坂本らの報 告より，円柱翼風車に作用する揚力は， $U$ と円柱翼のリング位置における回転速度 $V$ の比により求まる相対迎角 $\alpha$ に依存し，揚力から得られるトルクと円柱翼の軸受けのまさつなどによる回転に対する抵抗が釣り合うように $V$ が決定され定常回転となることが示された(坂本他, 2021). また, 円柱翼風車のトルク係数 $C_{q}$ は通常のプロペラ 型水平翼風車に比べて大きく, 定常回転する円柱翼の先端の周速比 $\lambda$ は 0.3 以下と, かなり低回転であることも 示された。 この高トルク低回転という特性により, 円柱翼を段付きとして回転に対する抵抗を低下させても低流 速域では $n$ に影響が現れなかったものと考えられる. 
図 11 に式(3)で定義した段付き円柱翼の $C_{d}$ とReの関係を示寸. 図 10(b)に示したように, 段付き円柱翼では単 独円柱翼よりも抗力はほぼ全ての流速域で減少したが，円柱翼の受風面も小さくなっているため, $C_{d}$ の值は $R e$ の全領域で単独円柱翼の $C_{d}$ を上回った。 また, 単独円柱翼では低い $R e$ の領域において $C_{d}$ は $R e$ の増加に伴い急 激に増加した。これに対し段付き円柱翼では， $C_{d}$ は $R e$ の全領域でほぼ一定に保たれた。これは単独円柱翼にお いて, リング状平板との交差部から離れた位置における翼周りの流れ場は，低い Re の領域ではネックレス渦の 安定した形成あるいはネックレス渦の強さに対して負の影響を与えていたことを示す．段付き円柱翼においても 翼端形状は変化しておらず，翼端渦の効果については単独円柱翼と同じであると予想されるため，この結果は主 としてリング状平板の内側の流れ場の改善によるネックレス渦の強化によるものと考えられる.

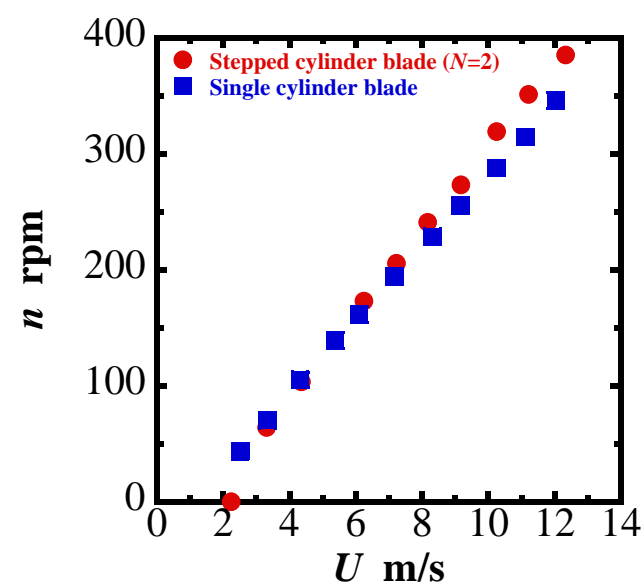

(a) Rotational speed vs. flow velocity

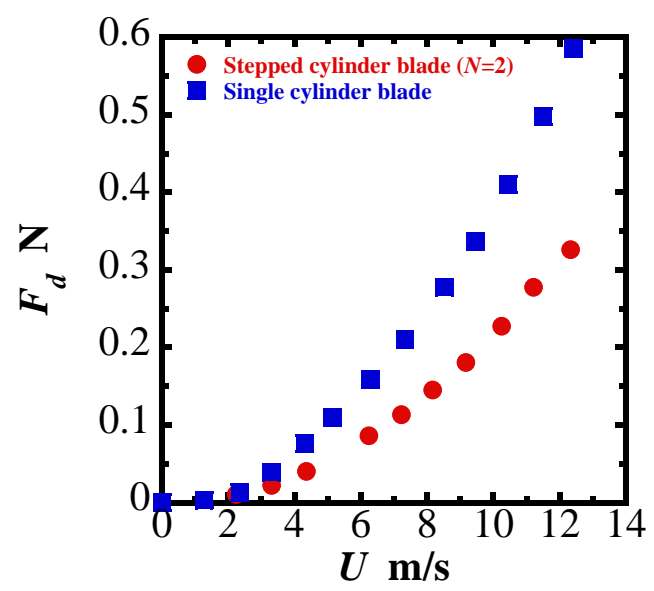

(b) Drag force vs. flow velocity

Fig. 10 The rotational speed and the drag force of rotating stepped cylinder blade at $N=2$, compared with results of single-cylinder blade. The stepped cylinder blade is more effective than the single-cylinder blade in reducing the drag force while maintaining the rotational speed.

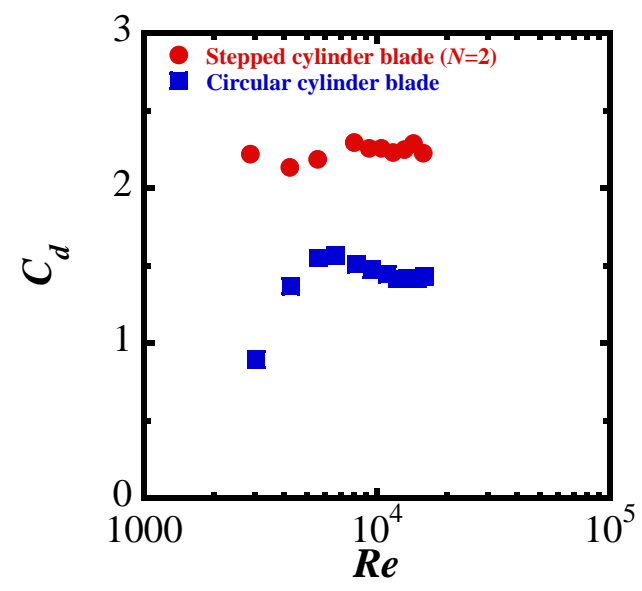

Fig. 11 The drag coefficient vs. Reynolds number of rotating stepped cylinder blade at $N=2$, compared with characteristics of singlecylinder blade. The drag force of the stepped cylinder blade is smaller than that of the single-cylinder blade in almost all flow velocity ranges, but due to the smaller wind receiving area of the cylinder blade, the value of drag coefficient is larger than that of the singlecylinder blade in all Re ranges. For the stepped cylinder blade, the drag force remains almost constant in all Re regions.

次に段付き円柱翼の多翼化による影響について検討する．回転円柱の条件（実験条件(1)）において，すき間比 を $s / d=0.35$, リング状平板の幅比を $W / d=1$ に設定し, 翼数を $N=2 \sim 12$ の間で変化させ回転数 $n$ と抗力 $F_{d}$ を測定し た. 図 12(a)に $n$ と $U$ の関係を示寸. $N$ にかかわらず，Uの増加に伴い $n$ は直線的に増加した. $N$ の増加により $n$ 
の増加率はわずかに増加するが $N=10$ において回転数が最大となり $N=12$ では他の翼数とほぼ同じに戻った. こ の様子を比較するため流速 $U=6,9,12 \mathrm{~m} / \mathrm{s}$ における各 $N$ の $n$ を抜き出し，図 12(b)にその関係を示した. $N$ によ り $n$ は多少変化するが, $N=10$ のときはいずれの $U$ においても他の $N$ の場合よりも大きな值を示した. $N=10$ と比 べて $N=12$ で $n$ が減少したことは，翼数が増加し円柱翼同士の間隔が狭くなることでネックレス渦の形成に対し て隣り合う円柱翼の流れ場が干渉し，ネックレス渦の形成を不安定化させる条件が存在する可能性を示している ものと考える. $F_{d}$ と $U$ の関係を図 13 に示す. $F_{d}$ はいずれの $N$ においても $U$ の増加に伴い急激に増加し $U \geq 4 \mathrm{~m} / \mathrm{s}$ の範囲では $N$ が大きいほど一定の $U$ における $F_{d}$ の值は大きくなった. $F_{d}$ は円柱翼すべての抗力の合計であるた め, 各 $N$ における円柱翼 1 つあたりの抗力 $F_{d} / N$ を求め, $N$ との関係を求めた. 図 14 に $U=12 \mathrm{~m} / \mathrm{s}$ における $F_{d} / N$ の 結果を示す. $F_{d} / N$ は $N=2$ において高い值を示し， $N=4$ で低下したあと $N$ の増加に対してわずかに増加した. 図 12 の $n$ に対して現れた $N=10$ の特異性は抗力に関しては現れず, 円柱翼 1 つたりの抗力は $N$ の変化に対して連 続的であることがわかった，これは， $N=10$ においてネックレス渦は他の $N$ と同様に形成されるが，回転を生み 出す揚力に対しては影響があることから，隣り合う円柱翼同士の間隔が流れに影響すると予想する．この隣り合 う円柱翼同士の間隔の変化が，ネックレス渦による揚力および抗力，さらに，回転に対する流体抵抗に及ぼす影 響の詳細については流れの可視化を含めさらなる検討が必要である. また, 円柱翼 1 つたりりの抗力係数として 式(3)で定義した $C_{d}$ により $N$ の効果を比較する. 図 15 に結果を示寸. $N=8$ において $R e=3100$ 付近の $C_{d}$ の值が極 端に大きいのは, ロードセルの計測限界に近かったことやベアリングの軸方向のまさつ抵抗に起因すると考えら れる. この $N=8$ わ $R e=3100$ 付近および $N=10$ を除き, $R e$ にして $C_{d}$ はほぼ一定值を示寸. $N=10$ では図 9 に示した 単独円柱翼の $W / d=1.5$ や 0.75 と同様に $R e$ が低い領域では $R e$ の増加に対して $C_{d}$ は増加し, 次第に増加率が低下 寸る挙動を示した. また, $N=2$ は他よりも高い $C_{d}$ 值を示すが，これは翼数が少ない事で相対的に式(3)において無 視した回転軸や八ブの抗力の効果が強く現れたものと考えられる.

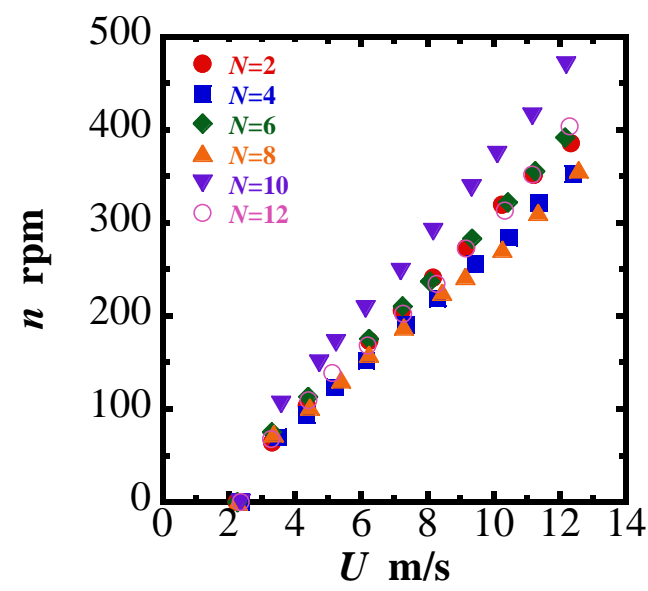

(a) Rotational speed vs. flow velocity

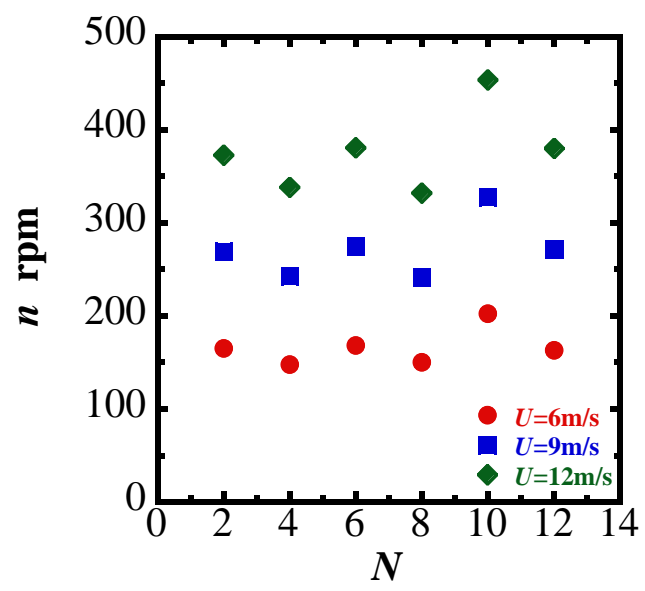

(b) Rotational speed vs. blade number at each flow velocity

Fig. 12 The rotation characteristics in each blade number $N$. The rotational speed increases linearly with the increase in flow velocity regardless of the blade number. For $N=10$, the rotational speed is larger than that for other blade numbers at all flow velocities. As the blade number increases and the distance between the stepped cylinder blades becomes narrower, the flow fields of adjacent stepped cylinder blades may destabilize the formation of necklace vortex. 


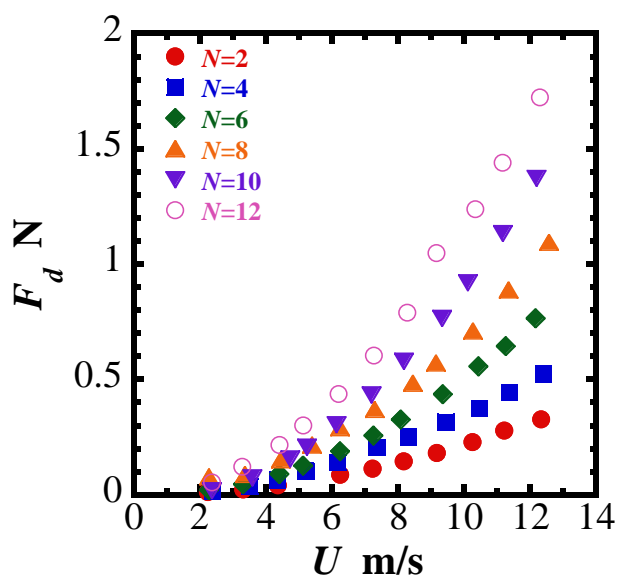

Fig. 13 The drag force vs. flow velocity in each blade number $N$. The drag force increases rapidly as the flow velocity increases in all blade number. As the blade number increases, the drag force increases at a constant flow velocity. in $U \geq 4 \mathrm{~m} / \mathrm{s}$.

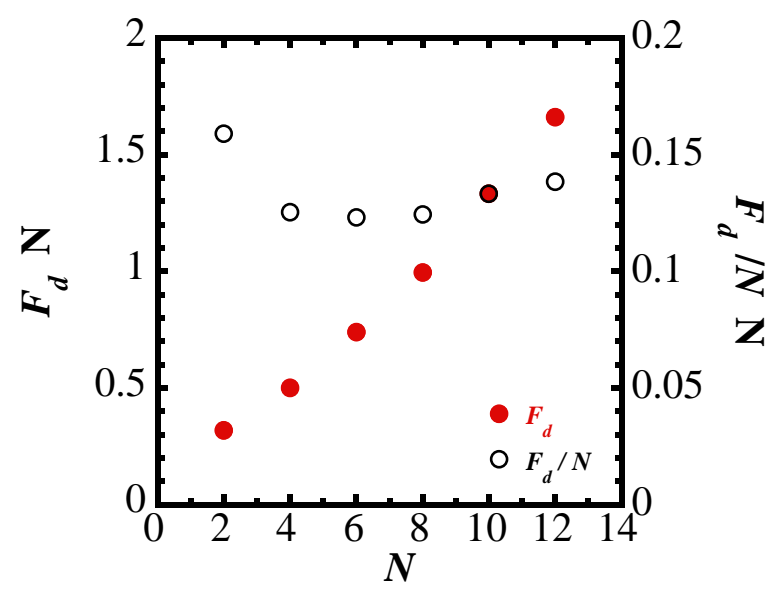

Fig. 14 The drag force characteristics of stepped cylinder blade in each blade number $N$ at $U=12 \mathrm{~m} / \mathrm{s}$. The drag force acting on the entire stepped cylinder blade $\left(F_{d}\right)$ increases almost linearly with the increase in the blade number. The drag force acting on per stepped cylinder blade $\left(F_{d} / N\right)$ shows a high value at $N=2$, decreases at $N=4$, and then increases slightly as the blade number increases. 


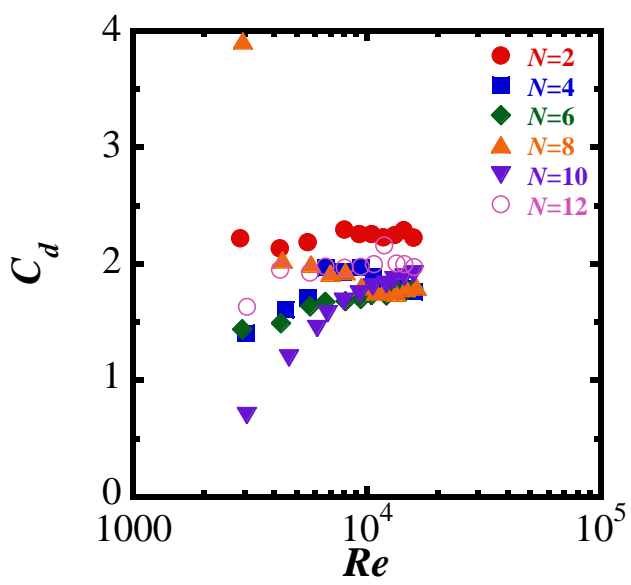

Fig. 15 The drag coefficient of rotating stepped cylinder blade in each blade number $N$. The drag coefficient is almost constant in $R e$ except for $N=10$. For $N=10$, as with $W / d=1.5$ and 0.75 for the single-cylinder blade, the drag coefficient increases with increasing $R e$ in the low $R e$, and the increase rate of the drag coefficient decreases with increasing $R e$. The value of drag coefficient for $N=2$ is higher than that for the other blade numbers, suggesting that the effect of the drag force by the driving shaft and hub, which is neglected in Eq. (3), is relatively stronger due to the smaller blade number.

\section{4. 結 論}

本研究では, 縦渦 (ネックレス渦) の揚力により駆動し定常回転する円柱翼風車の形状や構造パラメータの変 化による円柱翼周りの流れが，回転・抗力特性に及ぼす挙動を解明することを目的とし，円柱翼風車の定常回転 時の回転数および，円柱翼に作用する主流方向への抗力を風洞実験により調べた. 得られた結論を以下に示す.

1. 円柱翼移動方向の後方に縦渦の 1 つであるネックレス渦が形成されるとき, 円柱翼とその下流に配置された リング状平板の間に負圧領域が発生し, 円柱翼には回転方向への揚力の発生とともに主流方向への抗力が増 加した. 円柱翼が回転しない場合にもネックレス渦が不規則に形成されることから抗力は増加したが，回転 によりネックレス渦が定在化すると抗力はさらに増加した。

2. 単独円柱翼では，翼端やリング状平板よりも内側の領域の影響により，抗力係数は流速に対して増加する場 合や極大值を示す場合が観察された。一方，ネックレス渦の影響範囲以外を細くした段付き円柱翼では流速 に対して抗力係数がほぼ一定に保たれ，ネックレス渦の安定化が図られた.

3. 多翼化により抗力は増加するが円柱翼 1 つあたりでは翼数にかかわらず抗力はほぼ一定となった. 一方，翼 数が増加すると隣接する円柱翼の影響で回転数が増加する場合が生じた。このときも抗力には影響がなく， 円柱翼同士の間隔は円柱翼の回転数を決定する回転方向に作用する力にのみ影響した.

\section{文献}

Hemsuwan, W., Sakamoto, K. and Takahashi, T., Lift force generation of a moving circular cylinder with a strip-plate set downstream in cruciform arrangement: flow field improving using tip ends, International Journals of Aeronautical and Space Sciences, Vol. 19, Issue 3 (2018), pp.606-617.

Kato, N., Koide, M., Tahkahashi, T. and Shirakashi, M., VIVs of a circular cylinder with a downstream strip-plate in cruciform arrangement, Journal of Fluids and Structures, Vol. 30 (2012), pp.97-114.

小出瑞康, 高橋勉. 白樫正高, 風洞実験における低流速測定を目的としたリング流速計の試作, 日本機械学会論文 集 B 編, Vol. 67, No. 657 (2001), pp.1105-1111.

Koide, M., Ootani, K., Yamada, S., Takahashi, T. and Shirakashi, M., Vortex excitation caused by longitudinal vortices shedding from cruciform cylinder system in water flow, JSME International Journal Series B, Vol. 49, No. 4 (2006), pp.1043-1048.

Koide, M., Takahashi, T., Shirakashi, M. and Salim, S. A. Z. B. S., Three-dimensional structure of longitudinal vortices shedding from cruciform two-cylinder systems with different geometries, Journal of Visualization, Vol. 20, Issue 4 (2017), 
pp.753-763.

Kumagai, I., Matsumoto, T., Tahkahashi, T. and Shirakashi, M., Necklace vortex excitation of upstream cylinder in crisscross circular cylinder system, JSME International Journal Series B Fluids and Thermal Engineering, Vol. 44, Issue 4 (2001), pp.756-763.

Nguyen, T., Koide, M., Tahkahashi, T. and Shirakashi, M., Universality of longitudinal vortices shedding from a cruciform two circular cylinder system in uniform flow, Journal of Fluid Science and Technology, Vol. 5, Issue 3 (2010), pp.603615.

Nguyen, T., Koide, M., Yamada, S., Tahkahashi, T. and Shirakashi, M., Influence of mass and damping ratios on VIVs of a cylinder with a downstream counterpart in cruciform arrangement, Journal of Fluids and Structures, Vol. 28 (2012), pp.40-55.

坂本夏澄, 宇高啓太, Within Hemsuwan, 高橋勉, 縦渦の定常揚力により駆動する円柱翼風車の開発，日本機械学会 論文集, Vol. 87, No. 894 (2021).

Schlichting, H. and Gersten, K., Boundary layer theory 9th edition (2017), pp.18-19, Springer.

Shirakashi, M., Mizuguchi, M. and Bae, H. M., Flow-induced excitation of an elastically supported cylinder caused by another located downstream in cruciform arrangement, Journal of Fluids and Structures, Vol. 3 (1989), pp.595-607.

Shirakashi, M., Bae, H. M., Sano, M. and Takahashi, T., Characteristics of periodic vortex shedding from two cylinders in cruciform arrangement, Journal of Fluids and Structures, Vol. 8 (1994), pp.239-256.

Takahashi, T., Baranyi, L. and Shirakashi, M., Configuration and frequency of longitudinal vortices shedding from two cylinders in cruciform arrangement, Journal of the Visualization Society of Japan, Vol. 19, Issue 75 (1999), pp.328-336.

高橋勉, 吉武裕美子, 小又直, 植木由記子, 流体発電用回転装置および流体発電装置, 特願 2016-568339 (2016).

Takahashi, T., Yoshitake, Y., Sakamoto, K. and Hemsuwan, W., An innovative wind/water turbine with circular cylinder propeller driven by longitudinal vortex, Proceeding of the 15th World Wind Energy Conference and Exhibitions, PS-A-5 (2016).

\section{References}

Hemsuwan, W., Sakamoto, K. and Takahashi, T., Lift force generation of a moving circular cylinder with a strip-plate set downstream in cruciform arrangement: flow field improving using tip ends, International Journals of Aeronautical and Space Sciences, Vol. 19, Issue 3 (2018), pp.606-617.

Kato, N., Koide, M., Tahkahashi, T. and Shirakashi, M., VIVs of a circular cylinder with a downstream strip-plate in cruciform arrangement, Journal of Fluids and Structures, Vol. 30 (2012), pp.97-114.

Koide, M., Takahashi, T. and Shirakashi, M., Development of a ring-type vortex anemometer for low-velocity wind tunnel experiment, Transactions of the Japan Society of Mechanical Engineers Series B, Vol. 67, No. 657 (2001), pp. 1105-1111 (in Japanese).

Koide, M., Ootani, K., Yamada, S., Takahashi, T. and Shirakashi, M., Vortex excitation caused by longitudinal vortices shedding from cruciform cylinder system in water flow, JSME International Journal Series B, Vol. 49, No. 4 (2006), pp.1043-1048.

Koide, M., Takahashi, T., Shirakashi, M. and Salim, S. A. Z. B. S., Three-dimensional structure of longitudinal vortices shedding from cruciform two-cylinder systems with different geometries, Journal of Visualization, Vol. 20, Issue 4 (2017), pp.753-763.

Kumagai, I., Matsumoto, T., Tahkahashi, T. and Shirakashi, M., Necklace vortex excitation of upstream cylinder in crisscross circular cylinder system, JSME International Journal Series B Fluids and Thermal Engineering, Vol. 44, Issue 4 (2001), pp.756-763.

Nguyen, T., Koide, M., Tahkahashi, T. and Shirakashi, M., Universality of longitudinal vortices shedding from a cruciform two circular cylinder system in uniform flow, Journal of Fluid Science and Technology, Vol. 5, Issue 3 (2010), pp.603615.

Nguyen, T., Koide, M., Yamada, S., Tahkahashi, T. and Shirakashi, M., Influence of mass and damping ratios on VIVs of a cylinder with a downstream counterpart in cruciform arrangement, Journal of Fluids and Structures, Vol. 28 (2012), pp.40-55. 
Sakamoto, K., Udaka, K., Hemsuwan, W. and Takahashi T., Development of circular cylinder blade wind turbine driven by longitudinal vortex, Transactions of the JSME, Vol. 87, No. 894 (2021) (in Japanese).

Schlichting, H. and Gersten, K., Boundary layer theory 9th edition (2017), pp.18-19, Springer.

Shirakashi, M., Mizuguchi, M. and Bae, H. M., Flow-induced excitation of an elastically supported cylinder caused by another located downstream in cruciform arrangement, Journal of Fluids and Structures, Vol. 3 (1989), pp.595-607.

Shirakashi, M., Bae, H. M., Sano, M. and Takahashi, T., Characteristics of periodic vortex shedding from two cylinders in cruciform arrangement, Journal of Fluids and Structures, Vol. 8 (1994), pp.239-256.

Takahashi, T., Baranyi, L. and Shirakashi, M., Configuration and frequency of longitudinal vortices shedding from two cylinders in cruciform arrangement, Journal of the Visualization Society of Japan, Vol. 19, Issue 75 (1999), pp.328-336.

Takahashi, T., Yoshitake, Y., Komata, N. and Ueki, Y., Rotary device for fluid power generation and fluid power generation Device, Japanese Patent Application No. 2016-568339 (2016).

Takahashi, T., Yoshitake, Y., Sakamoto, K. and Hemsuwan, W., An innovative wind/water turbine with circular cylinder propeller driven by longitudinal vortex, Proceeding of the 15th World Wind Energy Conference and Exhibitions, PS-A-5 (2016). 